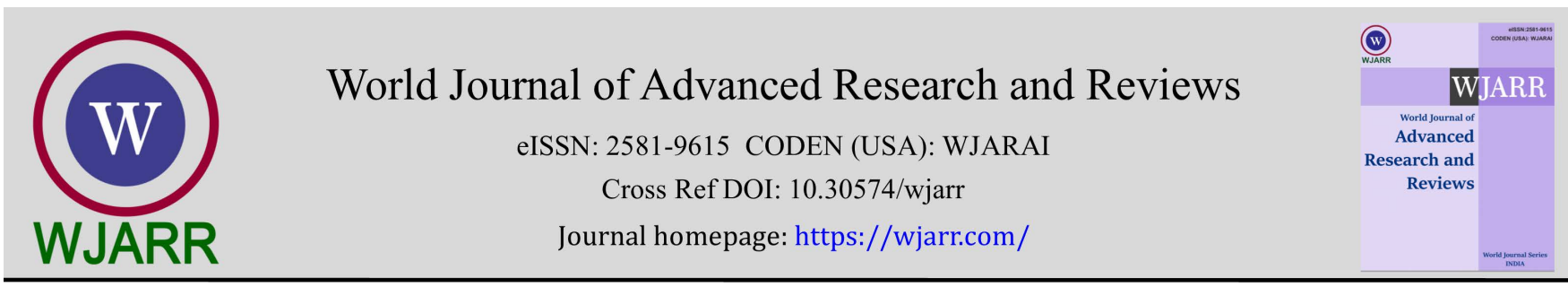

(REVIEW ARTICLE)

\title{
A review on the public health implications of heavy metals
}

\author{
Kafayat Kehinde Lawal ${ }^{1}$, Ike Kenneth Ekeleme ${ }^{1,}{ }^{*}$, Chinemerem Martin Onuigbo ${ }^{3}$, Victor Okezie Ikpeazu ${ }^{2}$ \\ and Smart Obumneme Obiekezie ${ }^{1}$ \\ ${ }^{1}$ Department of Microbiology, Nasarawa State University, Keffi, PMB 1022, Keffi, Nigeria. \\ 2 Department of Biochemistry, Abia state University Uturu, Abia State, Nigeria. \\ ${ }^{3}$ Department of Microbiology, Gregory University Uturu, PMB 1012 Amaokwe Achara Uturu, Abia State Nigeria.
}

World Journal of Advanced Research and Reviews, 2021, 10(03), 255-265

Publication history: Received on 26 April 2021; revised on 08 June 2021; accepted on 11 June 2021

Article DOI: https://doi.org/10.30574/wjarr.2021.10.3.0249

\begin{abstract}
In the recent years, the pollution of the environment by heavy metals has become a crucial problem across the world. Heavy metals consist of a group of metals and metalloids which have atomic density greater than $4000 \mathrm{~kg}$ m-3. Heavy metals such as Nickel (Ni), Cobalt (Co), Copper ( $\mathrm{Cu}$ ), Zinc ( $\mathrm{Zn})$, Lead (Pb) are present in the biota. These metals are also known as trace elements which play a very important role in various metabolic processes of plants, animals and microorganisms. Heavy metals may gain entrance into the human body through consumption of contaminated drinking water or ingestion of soil or crops grown on contaminated land. Heavy metals such as lead, mercury, cadmium and copper are collective poisons, which causes environmental hazards and are reported to be exceptionally toxic. These metals are important sources of oxidative stress in the cell and play an important role in a etiology of diverse human pathologies such as carcinogenesis. Exposure to heavy metal toxicity leads to brain damage, mental retardation, cerebral palsy, lung cancer, gastrointestinal abnormalities, dermatitis and death of the unborn fetus. Many metals have been shown to directly modify and/or damage DNA by forming DNA adducts that induce chromosomal breaks. The unrestricted access to the dumpsite means that each day, scavengers search for raw materials, much of which eventually finds its way back to neighborhoods as animal feed and even human food. Stray chicken, pigs, goats, dogs and cats roam the dumpsite eating the toxic matter and becoming vectors of pests and parasites that are eventually transferred to the surrounding home and hence causing diseases to both animals and human beings.
\end{abstract}

Keywords: Heavy metals; DNA; Lead; Zinc; human; animal

\section{Introduction}

Metals are substances with high electrical conductivity, malleability, and luster, which voluntarily lose their electrons to form cations. Metals are found naturally in the earth's crust and their compositions vary among different localities, resulting in spatial variations of surrounding concentrations. Metals are found all over the earth including the atmosphere, earth crust, water bodies, and can also accumulate in biological organisms including plants and animals. There 35 naturally existing metals, 23 of them have high specific density above $5 \mathrm{~g} / \mathrm{cm}^{3}$ with atomic weight greater than 40.04 and are called heavy metals [1,2]. Heavy metals include: Antimony, tellurium, bismuth, tin, thallium, gold, arsenic, cerium, gallium, cadmium, chromium, cobalt, copper, iron, lead, mercury, manganese, nickel, platinum, silver, uranium, vanadium, and zinc. Heavy metals are not just popular because of their specific high densities, they are also importantly known for their adverse effect on the ecosystem and living organisms.

Heavy metals such as Nickel, Cobalt, Copper, Zinc, Lead are present in the biota. These metals are also known as trace elements which play a very important role in various metabolic processes of plant, animal and microorganisms. They

\footnotetext{
${ }^{*}$ Corresponding author: Ike Kenneth Ekeleme

Department of Microbiology, Nasarawa State University, Keffi, PMB 1022, Keffi, Nigeria.
}

Copyright (C) 2021 Author(s) retain the copyright of this article. This article is published under the terms of the Creative Commons Attribution Liscense 4.0. 
are essential nutrients that are needed for various physiological and biochemical functions in the body and may lead to various deficiency diseases or syndromes if not available in adequate amounts but when present in large doses they may result to acute or chronic toxicities.

In the recent years, the pollution of the environment by heavy metals has become a crucial problem across the world. Albeit it been well known that heavy metals have many adverse health effects and last for a long period of time, the exposure of heavy metal continues and is increasing in many parts of the world. For ecological, evolutionary, nutritional and environmental reasons, Heavy metals are important environmental pollutants and their toxicity is a problem of flourishing significance [3,4]. Heavy metals gain access into the environment by natural means and through human activities. Soil erosion, natural weathering of the earth's crust, mining, industrial effluents, urban runoff, sewage discharge, insect or disease control agents applied to crops, and many others are peculiar sources of heavy metals [5].

Bioaccumulation of heavy metals develops as a result of different processes causing negative effects. These heavy metals are conveyed and compartmentalized into body cells and tissues binding to proteins, nucleic acids destroying these macromolecules and disrupting their cellular functions in the human body. The oxidative deterioration of biological macromolecules has been found by research to be primarily due to binding of heavy metals to the DNA and nuclear proteins [6]. Heavy metal toxicity in essence, can have several repercussions in the human body. The central nervous function can be affected leading to mental disorder, damage the blood constituents and may damage the lungs, liver, kidneys and other vital organs promoting several disease conditions [7].

This review brought to light the varied sources of heavy metals and the processes that encourage their exposure and bioaccumulation in the human body. It will also focus on the metabolism and mechanisms that leads to heavy metal toxicity. Toxic effects, signs and symptoms of heavy metals on human body will be discussed.

\subsection{Public health effect of Heavy metals}

Heavy metals may gain entrance into the human body through consumption of contaminated drinking water or ingestion of soil or crops grown on contaminated land $[8,9,10]$. Heavy metals such as lead, mercury, cadmium and copper are collective poisons, which causes environmental hazards and are reported to be exceptionally toxic [11]. These metals are important sources of oxidative stress in the cell and play an important role in a etiology of diverse human pathologies such as carcinogenesis [12,13,14]. Exposure to heavy metal toxicity leads to brain damage, mental retardation, cerebral palsy, lung cancer, gastrointestinal abnormalities, dermatitis and death of the unborn fetus [15].

Many metals have been shown to directly modify and/or damage DNA by forming DNA adducts that induce chromosomal breaks $[16,17]$. The unrestricted access to the dumpsite means that each day, scavengers search for raw materials, much of which eventually finds its way back to neighborhoods as animal feed and even human food. Stray chicken, pigs, goats, dogs and cats roam the dumpsite eating the toxic matter and becoming vectors of pests and parasites that are eventually transferred to the surrounding home and hence causing diseases to both animals and human beings.

Plant uptake of heavy metals from soils at high concentrations may lead to great health risks into considering the foodchain implications. Consumption of food crops contaminated with heavy metals is a major food chain route for human exposure. The food plants whose examination system is based on exhaustive and continuous cultivation have great capacity of extracting elements from soils. The cultivation of such plants in contaminated soil represents a potential risk since the vegetal tissues can accumulate heavy metals [18]. Heavy metals become toxic when they are not metabolized by the body and accumulate in the soft tissues [19]. Chronic level ingestion of toxic metals has undesirable impacts on humans and the associated harmful impacts become perceptible only after several years of exposure [20].

The water sources around the dumpsite also get contaminated with the heavy metals which results from leaching and also rain water which drains into them having passed through the dump. This contaminated water is further used for irrigating crops in close proximity and domestic use such as drinking and may literally cause heavy metal poisoning to the consumer. Allergies and skin infection may arise from using the water for bathing and laundry. The dumpsite also acts as a breeding ground for disease vectors causing serious health problems in the Vicinity.

\section{Heavy metals, their sources and toxicological effect}

Metals has important role in biological systems because a living cell cannot exist without metal ions. There are several heavy metals that are important for human health and many of them like $\mathrm{Zn}, \mathrm{Cu}, \mathrm{Ni}$, Fe and $\mathrm{Mn}$ are essential metal ions 
for living organisms in trace amount. However, if metals accumulate at high level or are ingested in large amounts, they can cause serious health problems [20].

\subsection{Cadmium}

Cadmium (Cd) is a member of group II-B of the periodic table and is a nearly uncommon metal which makes it rare in most natural soil and water. The production of this metal has increased expeditiously in the past few years. Cadmium is major component in semiconductors, nickel-cadmium batteries, electroplating, PVC, various alloys, pigments and control rods for nuclear reactors. Contamination of soil and water by Cadmium originates from mining and smelting industries, atmospheric pollution, sewage sludge application and burning of fossil fuels [21]. Symptoms characterized by the diseases caused by cadmium are bone pain, pathological fractures and signs of renal impairment. Cadmium toxicity targets organs such as liver, placenta, kidneys, lungs, brain and bones. Various researches on humans and animals have disclosed that osteoporosis (skeletal damage) is a significant effect of human exposure to cadmium together with disruptions in calcium metabolism, formation of renal stones and hypercalciuria. Depending on the severity of exposure, the symptoms of effects include nausea, vomiting, abdominal cramps, dyspnea and muscular weakness. Severe exposure may result in pulmonary oedema and death. Pulmonary effects (emphysema, bronchiolitis and alveolitis) and renal effects may occur following sub chronic inhalation exposure to cadmium and its compounds [22]. Cadmium and its compounds are highly water soluble in comparison to other metals. Their bioavailability is very high and hence it tends to bioaccumulate. Long-term exposure to cadmium can result in morphopathological changes in the kidneys. Smokers are more susceptible for cadmium intoxication than non-smokers. Presence of cadmium in smokers is as a result of tobacco. Tobacco plants, like other plants, have the ability to accumulate cadmium from the soil. Non-smokers are exposure is through food and some other pathways. Still, cadmium uptake through other pathways is much lower [23]. Cd is also affiliated with a disease called Itai-Itai, meaning "it hurts" in Japanese. Many clinical conditions namely; anosmia, cardiac failure cancers, cerebrovascular infarction, emphysema, osteoporosis, proteinuria cataract formation in the eyes have been more or less affiliated with cadmium. Cadmium interacts with essential nutrients through which it causes its toxicity effects. Experimental analysis in animals has shown that $50 \%$ of cadmium gets absorbed in the lungs and less in the gastrointestinal tract. Premature birth and reduced birth weights are the issues that arise if cadmium exposure is high during human pregnancy [24].

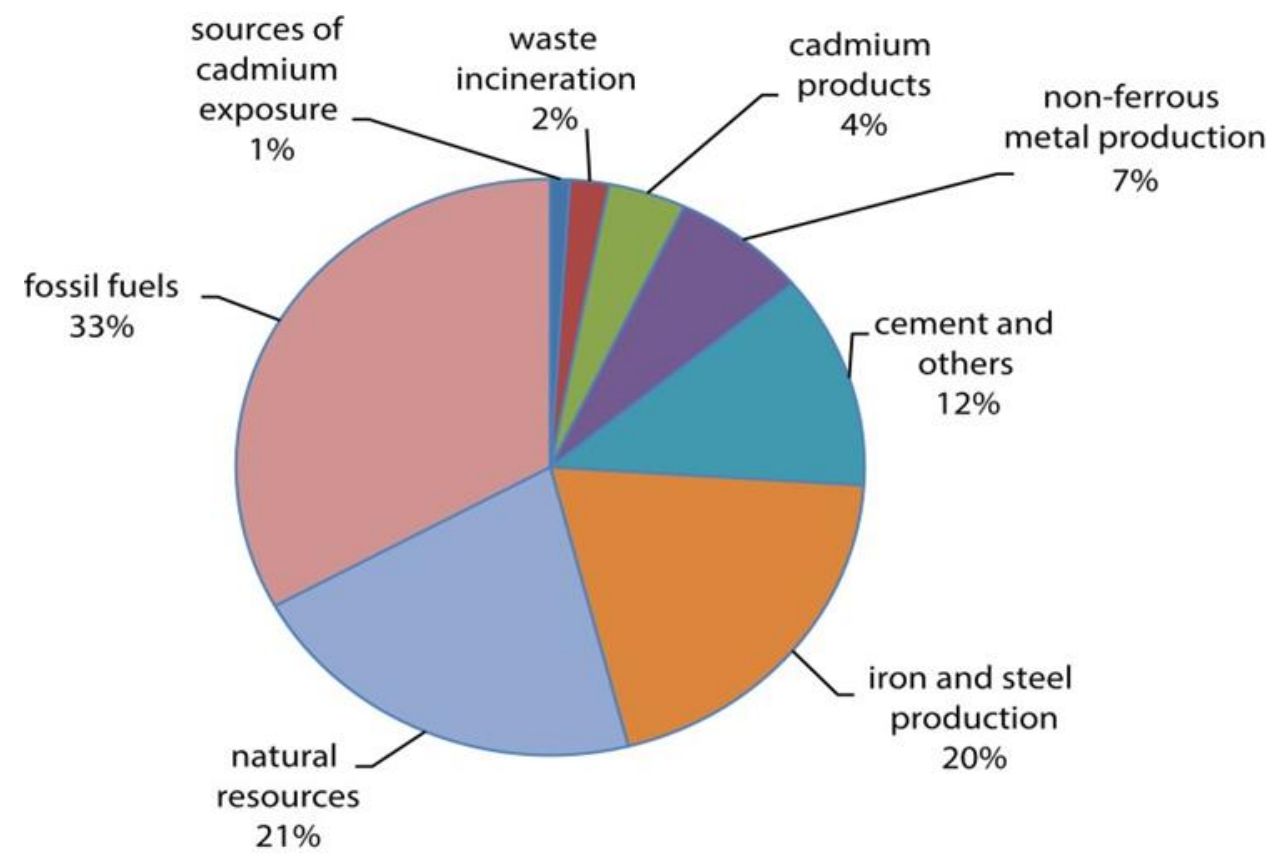

Figure 1 A relative contribution of different sources to human cadmium exposure [25]

\subsection{Arsenic}

Arsenic (As) belongs to group V-A of the periodic table. It is a very poisonous metalloid; it is chemically very similar to phosphorus and forms colorless crystalline oxides like $\mathrm{As}_{2} \mathrm{O}_{3}$ and $\mathrm{As}_{2} \mathrm{O}_{5}$ readily soluble in water. Species of arsenic have various applications such as insecticides, example, lead hydrogen arsenate, Scheele's green and more recently monosodium methyl arsenate. Arsenic has application in pyrotechnics, in bronzing and for hardening other metals. Other current uses include doping agent in solid-state devices and as a laser material (gallium arsenide) to change 
electricity into coherent light. Arsenic is gotten naturally and artificially as a result of weathered volcanic rocks, fossil fuels, agricultural chemicals, wood preservatives, medicinal products and industrial activities [26]. Arsenic pollution of the environment stems from the use of herbicides, fungicides and fertilizers [27]. Arsenite and arsenate are examples of inorganic arsenic that has been disclosed to be threatening to the general wellbeing of humans. They are known to be extremely carcinogenic and can lead to malignant growth of lungs, liver, bladder and skin. Arsenic gains access into the human body system through air, food and water. Portable drinking water soiled with arsenic is part of the critical reasons for arsenic detrimental effects in excess of 30 nations on the planet Earth. Cases whereby the arsenic level in ground water is 10-100 times above the value provided in the WHO guideline for drinking water $(10 \mu \mathrm{g} / \mathrm{L})$, it can be injurious to human health [28]. Contamination of water may occur through indiscriminate disposal of arsenical chemicals, arsenical pesticides or by natural mineral deposits. Arsenic toxicity can be either acute or chronic. Chronic arsenic toxicity is known as arsenicosis. Majority of the research on chronic arsenic toxicity in man is focused on its effect on the skin because of its specificity in diagnosis. Pigmentation and keratosis are the specific skin lesions that shows chronic arsenic toxicity [29]. Albeit highly toxic and cancer-causing, a few forms of this metal have been adapted in the treatment of some diseases namely syphilis and cancer.

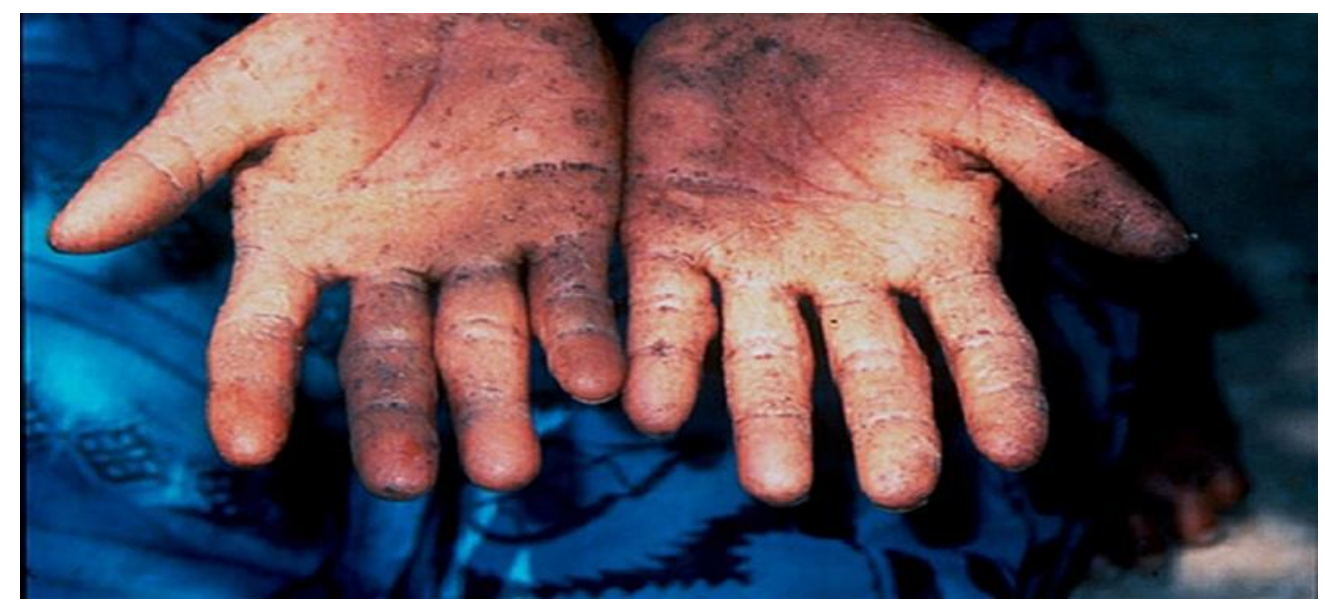

Figure 2 Arsenic keratosis, also called "raindrops on a dusty road" (available from: http://www.pathologyoutlines.com/topic/bonemarrarsenic.html)

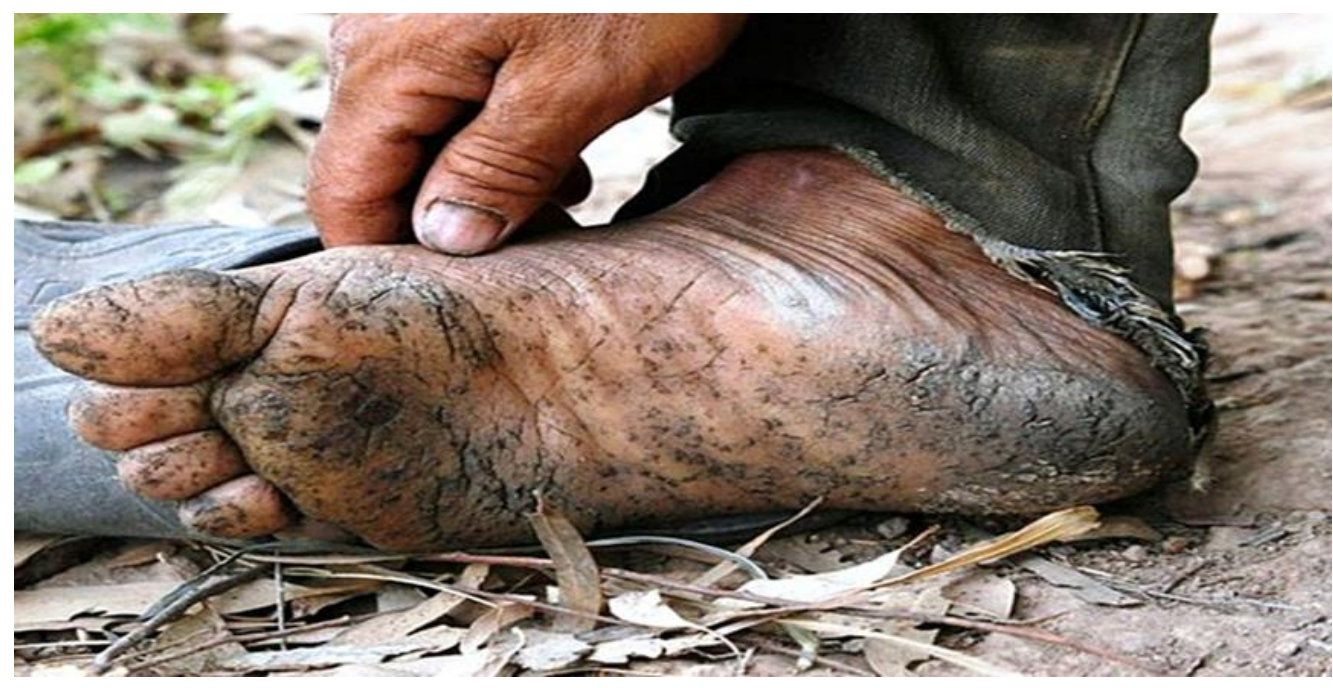

Figure 3 Skin lesions due to arsenicosis [30]

\subsection{Zinc}

Zinc (Zn) is a member of group II-B of the periodic table and it is relatively abundant. Zn is a bluish-white lustrous metal and is averagely reactive. It combines with oxygen and other non-metals. The well-known oxidation state of zinc is $\mathrm{Zn}^{2+}$. $\mathrm{Zn}$ is frequently used in corrosion-resistant steel coatings, brass alloys, paint pigments, wood preservatives, dry-cell batteries, cosmetics and pharmaceuticals [31]. Large quantity of Zn has found various applications in the industries such as the production of die-castings, which promotes its release to the atmosphere, water and soil [32]. Major sources 
of $\mathrm{Zn}$ contamination in the environment are industrial wastes, metal plating and acid mine drainage. Sewage and animal wastes makeup for the source of zinc in soils. Although not of utmost importance, it is well established that soils possess the innate capability to accumulate high concentrations of zinc.

$\mathrm{Zn}$ as opposed to both heavy metals discussed above is a vital trace element required for life of animals, plants and bacteria. It is noticed that human proteins contain $\mathrm{Zn}$ which portrays a valuable role in the catalytic activity of proteins. This crucial trace metal is used in several biological processes, is valuable for the proper maturation of sex organs and bone growth, most importantly in the fetuses. On the other hand, Zn at elevated levels becomes injurious to health [33]. Evidence portraying Zn deficiency in animals are as follows: hair loss, skin lesions, and diarrhea and growth depression. Typical indications of zinc deficiency in plants are interveinal chlorosis, impaired growth, and malformation of stems and leaves. Despite Zn being an essential element, excess of this metal causes reduced weight in animals, reduced iron function, impaired immune system, and nausea. High concentrations of Zn can also interact with thiols and block essential reaction on the cell [34]. $\mathrm{Zn}$ is phytotoxic in large quantities.

\subsection{Chromium}

Chromium (Cr) is popularly known as the two-faced metal, its ability to be of advantage or disadvantage humans and animals largely depends on its oxidation state and concentration [35]. Chromium, which mostly originates from several industries, occurs in different oxidation states but $\mathrm{Cr}$ (III) and $\mathrm{Cr}$ (VI) are the most significant [36]. Cr (III) is regarded a trace element vital for proper functioning of living organisms [14]. It is broadly used in industries such as electroplating, paint and pigment manufacturing, textile, fertilizer and leather tanning. Most of these industries indiscriminately expel trivalent and hexavalent chromium with waste effluent to the soil and surface water. Hexavalent chromium is acutely toxic, mutagenic, and carcinogenic. Additionally, $\mathrm{Cr}$ (VI) is soluble in nature which makes it highly mobile in most environments. In spite of the heavy metals being acutely toxic to most microbes, there are metal-tolerant bacteria. In the aspect of nutrition, at reduced concentrations, $\mathrm{Cr}$ (III) is a valuable component of a much-needed human and animal diet for impeding negative effects in the metabolism of glucose and lipids, example, impaired glucose tolerance, increased fasting insulin, increased cholesterol and triglycerides, and hypoglycemic symptoms [37]. Cr (III) at huge concentrations can interfere with several metabolic processes due to its high capacity to coordinate numerous organic compounds leading to inhibition of some metal-enzyme systems [35]. Hexavalent chromium is known to have carcinogenic and mutagenic properties affecting mammals including human beings [38]. Chromium causes cancer of bladder, allergic dermatitis and nasopharyngeal cancer [39].

Schroeder et al. [40] revealed that cigarettes contained $390 \mathrm{~g} / \mathrm{kg}$ of $\mathrm{Cr}$, but there has been no concrete report published on the quantity of chromium inhaled through smoking. When injured skin comes in contact with any type of chromium compounds, a deeply penetrating hole will be formed. Exposure to chromium compounds can result in the formation of ulcers, which will persist for months and heal very slowly. Ulcers on the nasal septum are very common in case of chromate workers. Humans, being exposed to considerably huge amounts of chromium compounds can bring about the inhibition of erythrocyte glutathione reductase, which as a result, lowers the capacity to reduce methemoglobin to hemoglobin. Conclusion gotten from different in vitro and in vivo experiments have shown that chromate compounds can incite DNA damage in many different ways and can lead to the development of DNA adducts, chromosomal aberrations, sister chromatid exchanges, alterations in replication and transcription of DNA [41,42].

\subsection{Lead}

Lead $(\mathrm{Pb})$ is biologically non-essential. This metal is a notable pollutant that is found in soil, water and air as a hazardous waste. It is highly toxic to human, animals, plants and microbes $[43,44]$. The notable sources of lead are petroleum, electronic industries, battery, paint, stained glass and biocide preparation. The use of leaded gasoline in cars is one of the major sources of $\mathrm{Pb}$ pollution in metropolis around the world. According to research, an estimated value of over a thousand tons $\mathrm{Pb}$ is produced by road traffic each year, as a result of lead additives in petrol. Soils, plants and food are major receptacles for these atmospheric emissions. Only 3\% of $\mathrm{Pb}$ in soil is translocated through the root to the shoot of plants while the rest is through foliage. Research on smoked fish food exposed to highways indicated a relationship between the vehicular traffic volume and the fish Pb levels [45] which is a potential threat to the health, security and safety of such food items. Lead is one of the dangerous heavy metals found in environment. This metal affects systems of the human body. Lead on low doses cause developmental disorder in fetuses, infants and young children, brain damage, respiratory problems, intoxication of central nervous system and male infertility [46]. Lead toxicity is targeted towards the memory and learning processes of the brain and can be mediated through three processes. Lead can impair learning and memory in the brain by inhibiting the N-methyl-d-aspartate receptor (NMDAR) and can block neurotransmission by inhibiting neurotransmitter release, block the neuronal voltage-gated calcium (Ca2+) channels (VGCCs) and reduce the expression of brain-derived neurotrophic factor (BDNF). 


\subsection{Mercury}

Mercury is considered the most toxic heavy metal in the environment. Mercury poisoning is referred to as acrodynia or pink disease. Mercury is released into the environment through the daily running of various industries such as pharmaceuticals, paper and pulp preservatives, agriculture industry, and chlorine and caustic soda production industry [5]. Organic and inorganic mercury can be produced through its capability to combine with other elements. Continuous exposure to increased levels of metallic, organic and inorganic mercury can maim the brain, kidneys and the developing fetus [47].

Table 1 Types of mercuric toxicity

\begin{tabular}{|c|c|c|c|}
\hline & Elemental mercury & Methyl mercury & Inorganic mercury \\
\hline Sources & $\begin{array}{l}\text { Fossil fuels, dental } \\
\text { amalgams, old latex } \\
\text { paint, incinerators, } \\
\text { thermometers }\end{array}$ & $\begin{array}{l}\text { Pesticides, fish, } \\
\text { poultry }\end{array}$ & $\begin{array}{l}\text { Biological oxidation of } \\
\text { mercury, } \\
\text { demethylation of } \\
\text { methyl mercury by } \\
\text { intestinal microflora }\end{array}$ \\
\hline Absorption & $\begin{array}{l}75-85 \% \text { of vapor } \\
\text { absorbed }\end{array}$ & $\begin{array}{l}95-100 \% \text { absorbed in } \\
\text { intestinal tract }\end{array}$ & $\begin{array}{l}7-15 \% \text { of ingested } \\
\text { dose absorbed and 2- } \\
3 \% \text { dermal dose } \\
\text { absorbed in animals }\end{array}$ \\
\hline Distribution & $\begin{array}{l}\text { Distributed } \\
\text { throughout the body, } \\
\text { lipophilic, crosses } \\
\text { blood-brain barrier } \\
\text { and placental } \\
\text { barrier, accumulates } \\
\text { in brain and kidney }\end{array}$ & $\begin{array}{l}\text { Distributed } \\
\text { throughout the body, } \\
\text { lipophilic readily } \\
\text { crosses blood-brain } \\
\text { barrier as well as } \\
\text { placental barrier, } \\
\text { accumulates in } \\
\text { kidney and brain }\end{array}$ & $\begin{array}{l}\text { Does not cross blood- } \\
\text { brain or placental } \\
\text { barrier, present in } \\
\text { brain neonates, } \\
\text { accumulates in kidney }\end{array}$ \\
\hline Excretion & $\begin{array}{l}\text { Sweat, urine, faeces, } \\
\text { and saliva }\end{array}$ & $\begin{array}{l}90 \% \text { excreted in bile, } \\
\text { faeces, } 10 \% \text { in urine }\end{array}$ & $\begin{array}{l}\text { Sweat, saliva, urine and } \\
\text { faeces }\end{array}$ \\
\hline $\begin{array}{l}\text { Reason } \\
\text { toxicity }\end{array}$ & $\begin{array}{l}\text { Oxidation to } \\
\text { inorganic mercury }\end{array}$ & $\begin{array}{l}\text { Demethylation to } \\
\text { inorganic mercury, } \\
\text { generation of free } \\
\text { radical, binding to } \\
\text { thiols in enzymes and } \\
\text { structural proteins }\end{array}$ & $\begin{array}{l}\text { Binding to thiols in } \\
\text { enzymes and } \\
\text { structural proteins }\end{array}$ \\
\hline
\end{tabular}

Mercury is present in most foods and beverages in the range $<1$ to $50 \mu \mathrm{g} / \mathrm{kg}$. In marine foods it is often seen at higher levels. Organic mercury can easily permeate across the bio membranes and since they are lipophilic in nature, mercury is present in higher concentrations in most species of fatty fish and in the liver of lean fish. Micro-organisms convert the mercury present in soil and water into methyl mercury, a toxin which can accumulate with fish age and with increasing trophic levels. EPA has declared mercuric chloride and methyl mercury to be highly carcinogenic. The nervous system is very sensitive to all types of mercury. Increased exposure of mercury can alter brain functions and lead to shyness, tremors, memory problems, irritability, and changes in vision or hearing. Exposure to metallic mercury vapors at higher levels for shorter periods of time can lead to lung damage, vomiting, diarrhea, nausea, skin rashes, increased heart rate or blood pressure. Symptoms of organic mercury poisoning include depression, memory problems, tremors, fatigue, headache, hair loss, etc. Since these symptoms are common also in other conditions, it may be difficult to diagnose such cases [29]. Due to the excess health effects associated with exposure to mercury, the present standard for drinking water has been set at lower levels of $0.002 \mathrm{mg} / \mathrm{L}$ and $0.001 \mathrm{mg} / \mathrm{L}$ by the Environmental Protection Act and World Health Organization. 
Table 2 Regulatory limit of selected heavy metals

\begin{tabular}{|l|c|c|c|}
\hline $\begin{array}{l}\text { Heavy } \\
\text { metals }\end{array}$ & $\begin{array}{l}\text { EPA limits in drinking } \\
\text { water (ppm) }\end{array}$ & $\begin{array}{l}\text { OSHA limit in } \\
\text { workplace air (mg) }\end{array}$ & $\begin{array}{l}\text { FDA limit in bottled } \\
\text { water/food (ppm) }\end{array}$ \\
\hline Arsenic & 0.01 & 10 & - \\
\hline Cadmium & 0.0005 & 5 & 0.0005 \\
\hline Chromium & 0.1 & 1 & 1 \\
\hline Lead & 0.015 & 0.15 & - \\
\hline Mercury & 0.002 & 0.1 & - \\
\hline Zinc & 5 & 5 & - \\
\hline
\end{tabular}

\section{Mechanism of toxicity of heavy metals}

\subsection{Cadmium}

The effect of Cadmium toxicity on cells is known but its mechanism of toxicity is not well understood. Cadmium concentration rises 3,000-fold as it binds to metallothionein which is a cystein-rich protein. Hepatotoxicity is caused by the cystein-metallothionein complex in the liver, which then circulates to the kidney and gets accumulated in the renal tissue causing nephrotoxicity. Cadmium poses the ability to bind with cystein, glutamate, histidine and aspartate ligands and can result in the deficiency of iron [48]. The same oxidation state is possessed by Cadmium and zinc and hence cadmium can replace zinc present in metallothionein, thereby inhibiting it from acting as a free radical scavenger within the cell.

\subsection{Arsenic}

In the biotransformation of arsenic, inorganic arsenic compounds that are harmful are methylated by bacteria, algae, fungi and humans to poduce monomethylarsonic acid (MMA) and dimethylarsinic acid (DMA). These inorganic arsenic species (iAs) are changed by enzymes to methylated arsenicals which are the end metabolites and the biomarker of chronic arsenic exposure in this biotransformation process.

$\mathrm{iAs}(\mathrm{V}) \rightarrow \mathrm{iAs}(\mathrm{III}) \rightarrow \mathrm{MMA}(\mathrm{V}) \rightarrow \mathrm{MMA}(\mathrm{III}) \rightarrow \mathrm{DMA}(\mathrm{V})$

Biomethylation is a detoxification process and end products are methylated inorganic arsenic such as MMA (V) and DMA (V), which excreted through urine are bioindication of chronic arsenic exposure. However, MMA (III) is not excreted and remains inside the cell as an intermediate product.

Monomethylarsonic acid (MMA III), an intermediate product, is found to be highly toxic compared to other arsenicals, potentially accountable for arsenic-induced carcinogenesis.

\subsection{Chromium}

Due to its weak membrane permeability, trivalent chromium Cr (III) is generally harmless in the environment. On the other hand, hexavalent chromium $\mathrm{Cr}$ (VI), is more active in penetrating the cell membrane through passages for isoelectric and isostructural anions such as $\mathrm{SO}_{4}{ }^{2-}$ and $\mathrm{HPO}_{4}{ }^{2-}$ channels and these chromates are taken up through phagocytosis. Cr (VI) is a strong oxidizing agent and can be reduced to give ephemeral species of pentavalent and tetravalent chromium that are different from that of $\mathrm{Cr}$ (III). Stabilization of the pentavelent form is carried out by glutathione and hence intracellular reduction of $\mathrm{Cr}[\mathrm{VI}]$ is considered a detoxification mechanism when reduction occurs away from the target region. However, if intracellular reduction of $\mathrm{Cr}$ [VI] occurs near the target site, it may serve to activate $\mathrm{Cr}$. The reactions between $\mathrm{Cr}(\mathrm{VI})$ and biological reductants like thiols and ascorbate result in the production of reactive oxygen species such as superoxide ion, hydrogen peroxide, and hydroxyl radical, ultimately leading to oxidative stress in the cell causing damage to DNA and proteins. According to literature surveys, Cr (VI) has been found to be much more dangerous than $\mathrm{Cr}$ (III), since $\mathrm{Cr}$ (VI) enters the cells more readily than does Cr (III) and is eventually reduced to $\mathrm{Cr}$ (III). Because of its mutagenic properties, $\mathrm{Cr}$ (VI) is categorized as a group 1 human carcinogen by the International Agency for the Research on Cancer. 


\subsection{Lead}

Lead metal causes toxicity in living cells by following ionic mechanism and that of oxidative stress. Many researchers have shown that oxidative stress in living cells is caused by the imbalance between the production of free radicals and the generation of antioxidants to detoxify the reactive intermediates or to repair the resulting damage. Antioxidants, as e.g. glutathione, present in the cell protect it from free radicals such as $\mathrm{H}_{2} \mathrm{O}_{2}$. Under the influence of lead, however, the level of the Reactive Oxygen species (ROS) increases and the level of antioxidants decreases. Since glutathione exists both in reduced (GSH) and oxidized (GSSG) state, the reduced form of glutathione gives its reducing equivalents $\left(\mathrm{H}^{+}+\right.$ $\mathrm{e}^{-}$) from its thiol groups of cystein to ROS in order to make them stable. In the presence of the enzyme glutathione peroxidase, reduced glutathione readily binds with another molecule of glutathione after donating the electron and forms glutathione disulfide (GSSG). The reduced form (GSH) of glutathione accounts for $90 \%$ of the total glutathione content and the oxidized form (GSSG) accounts for 10\% under normal conditions. Yet under the condition of oxidative stress, the concentration of GSSG exceeds the concentration of GSH. Another biomarker for oxidative stress is lipid peroxidation, since the free radical collects electron from lipid molecules present inside the cell membrane, which eventually causes lipid peroxidation [49]. At very high concentrations, ROS may cause structural damage to cells, proteins, nucleic acid, membranes and lipids, resulting in a stressed situation at cellular level.

The ionic mechanism of lead toxicity occurs mainly due to the ability of lead metal ions to replace other bivalent cations like $\mathrm{Ca}^{2+}, \mathrm{Mg}^{2+}, \mathrm{Fe}^{2+}$ and monovalent cations like $\mathrm{Na}^{+}$, which ultimately disturbs the biological metabolism of the cell. The ionic mechanism of lead toxicity causes significant changes in various biological processes such as cell adhesion, intraand inter-cellular signaling, protein folding, maturation, apoptosis, ionic transportation, enzyme regulation, and release of neurotransmitters. Lead can substitute calcium even in picomolar concentration affecting protein kinase $\mathrm{C}$, which regulates neural excitation and memory storage.

\subsection{Mercury}

Mercury is well known as a hazardous metal and its toxicity is a common cause of acute heavy metal poisoning with cases of 3,596 in 1997 by the American Association of Poison Control Centers. Methylmercury is a neurotoxic compound which has been implicated for microtubule destruction, mitochondrial damage, lipid peroxidation and accumulation of neurotoxic molecules such as serotonin, aspartate, and glutamate [50]. The accumulated quantity of mercury deposition into the environment has been assessed at 2,200 metric tons. It is estimated that 8 to $10 \%$ of American women have mercury levels that would induce neurological disorders in any child they birth, according to both the Environmental Protection Agency and National Academy of Science. Serious neurological and behavioral changes have been reported on animals exposed to toxic mercury. Rabbits when exposed to $28.8 \mathrm{mg} / \mathrm{m} 3$ mercury vapor for a period of 1 to 13 weeks have shown slight pathological changes, marked cellular degeneration and brain necrosis.

The brain remains the target organ for mercury, yet it can damage any organ and lead to malfunctioning of nerves, kidneys and muscles. It can cause disruption to the membrane potential and interrupt with intracellular calcium homeostasis. Mercury binds to freely available thiols as the stability constants are high [50]. Mercury vapors can cause bronchitis, asthma and temporary respiratory problems. Mercury plays a key role in damaging the tertiary and quaternary protein structure and alters the cellular function by attaching to the selenohydryl and sulfhydryl groups which undergo reaction with methyl mercury and hamper the cellular structure. It also intervenes with the process of transcription and translation resulting in the disappearance of ribosomes and eradication of endoplasmic reticulum and the activity of natural killer cells. The cellular integrity is also affected causing free radical formation. The basis for heavy metal chelation is that even though the mercury sulfhydryl bond is stable and divided to surrounding sulfhydryl consisting ligands, it also contributes free sulfhydryl groups to promote metal mobility within the ligands.

\section{Conclusion}

In this survey, we evaluated the impacts of some heavy metals, for example arsenic, lead, mercury, cadmium, chromium, aluminum and iron, on nature and living life forms, for the most part humans. Effective laws, rules and discovery of the territories where there are more elevated levels of heavy metals are fundamental. Inability to control the presence of heavy metals will bring about extreme inconveniences in future due to the unfriendly impacts forced by them. Work related presentation to heavy metals can be diminished by creating working solutions. Monitoring the exposure and probable intervention for reducing additional exposure to heavy metals in the environment and in humans can become a momentous step towards prevention. National as well as international co-operation is vital for framing appropriate tactics to prevent heavy metal toxicity. 


\section{Compliance with ethical standards}

\section{Acknowledgments}

I appreciate Ezekiel Dodo Kpeme, Faith Ufedo-ojo Alfa and Danjuma Adanu Adamu for their help in data collection and analysis.

\section{Disclosure of conflict of interest}

No conflicting interest

\section{References}

[1] Duffus JH. Heavy metals-A meaningless term? Pure and Applied Chemistry. 2002; 74(5): 793-807.

[2] Li F, Qiu ZZ, Zhang JD. Investigation, pollution mapping and simulative leakage health risk assessment for heavy metals and metalloids in groundwater from a typical brownfield, middle China. International Journal of Environmental Research and Public Health. 2017; 14(7): 768.

[3] Jaishankar M, Mathew BB, Shah MS, Gowda KRS. Biosorption of Few Heavy Metal Ions Using Agricultural Wastes. Journal of Environment Pollution and Human Health. 2014; 2(1): 1-6.

[4] Nagajyoti PC, Lee KD, Sreekanth TVM. Heavy metals, occurrence and toxicity for plants: a review. Environmental Chemistry Letters. 2010; 8(3): 199-216.

[5] Morais S, Costa FG, Pereira ML. Heavy metals and human health. In: Oosthuizen J, editor. Environmental health emerging issues and practice. 2012; 227-246.

[6] Flora SJS, Mittal M, Mehta A. Heavy metal induced oxidative stress \& its possible reversal by chelation therapy. Indian Journal of Medical Research. 2008; 128: 501-523.

[7] Monisha J, Tenzin T, Naresh A, Blessy BM, Krishnamurthy NB. Toxicity, mechanism and health effects of some heavy metals. Interdisciplinary Toxicology. 2014; 7(2): 60-72.

[8] Wuana RA, Okieimen FE. Heavy Metals in Contaminated Soils: A Review of Sources, Chemistry, Risks and Best Available Strategies for Remediation. International Scholarly Research Notices. 2011; 402647: 1-20.

[9] Andresen E, Peiter E, Küpper H. Trace metal metabolism in plants. Journal of Experimental Botany. 2018; 69(5): 909-954.

[10] Rai PK, Lee SS, Zhang M, Tsangd YF, Kim KH. Heavy metals in food crops: Health risks, fate, mechanisms, and management. Environment International. 2019; 125: 365-385.

[11] Yargholi B, Azimi AA. Investigation of Cadmium absorption and accumulation in different parts of some vegetables. American Eurasian Journal of Agriculture and Environmental Science. 2008; 3: 357-364.

[12] Leonard SS, Bower JJ, Shi X. Metal-induced toxicity, carcinogenesis, mechanisms and cellular responses. Molecular Cell Biochemistry. 2004; 255(1-2): 3-10.

[13] Hei TK, Filipic M. Role of oxidative damage in the genotoxicity of arsenic. Free Radical Biology and Medicine. 2004; 37: 574-581.

[14] Wang F, Yao J, Si Y, Chen H, Russel M, Chen K, Qian Y, Zaray G, Bramanti E. Short-time effect of heavy metals upon microbial community activity. Journal of Hazardous Materials. 2010; 173: 510-516.

[15] Rotich KH, Zhao Y, Dong J. Municipal solid waste management challenges in the developing countries- Kenyan case study. Waste Management. 2006; 26: 92-100.

[16] Wise S, Holmes A, Wise J. Hexavalent Chromium-Induced DNA Damage and Repair Mechanisms. Reviews on environmental health. 2008; 23: 39-57.

[17] Jordao CP, Nascentes CC, Cecon PR, Fontes RLF, Pereira JL. Heavy metal availability in soil amended with composted urban solid wastes. Environmental Monitoring and Assessment. 2006; 112: 309-326.

[18] Sobha K, Poornima A, Harini P, Veeraiah K. A study on biochemical changes in the fresh water fish, catla catla (hamilton) exposed to the heavy metal toxicant cadmium chloride. Kathmandu University Journal of Science, Engineering and Technology. 2007; 1(4): 1-11. 
[19] Khan S, Cao Q, Zheng YM, Huang YZ, Zhu YG. Health risks of heavy metals in contaminated soils and food crops irrigated with wastewater in Beijing, China. Environmental Pollution. 2008; 152: 686-692.

[20] Gupta N, Kumar, V. Identification and Isolation of heavy metal (Copper) resistant bacteria. Archives of Applied Science Research. 2012; 4(1): 577-583.

[21] Faroon 0, Ashizawa A, Wright S. Toxicological Profile for Cadmium. Atlanta (GA): Agency for Toxic Substances and Disease Registry (US). 6 Sep 2012.

[22] Duruibe J0, Ogwuegbu MOC, Egwurugwu JN. Heavy metal pollution and human biotoxic effects. International Journal of Physical Sciences. 2007; 2(5): 112-118.

[23] Mudgal V, Madaan N, Mudgal A, Singh RB, Mishra S. Effect of toxic metals on human health. Open Nutraceuticals Journal. 2010; 3: 94-99.

[24] Henson MC, Chedrese PJ. Endocrine disruption by cadmium, a common environmental toxicant with paradoxical effects on reproduction. Experimental Biology and Medicine (Maywood). 2004; 229(5): 383-392.

[25] Regoli L. The Relative Contributions of Different Environmental Sources to Human Exposure and the EU Cadmium Risk Assessment Meeting of UNECE Task Force on Heavy Metals. Presentation for the UNECE LongRange-Trans-boundary Air Pollutants - Task Force on Heavy Metals. 2005.

[26] Garelick H, Jones H, Dybowska A, Valsami-Jones E. Arsenic Pollution Sources. Reviews of environmental contamination and toxicology. 2008; 197: 17-60.

[27] Jackson CR, Dugas SL, Harrison KG. Enumeration and characterization of arsenate-resistant bacteria in arsenic free soils. Soil Biology \& Biochemistry. 2005; 37: 2319-2322.

[28] Hoque MA, Burgess WG, Shamsudduha M, Ahmed KM. Delineating low-arsenic groundwater environments in the Bengal Aquifer System, Bangladesh. Journal of Applied Geochemistry. 2011; 26(4): 614-623.

[29] Martin S, Griswold W. Human health effects of heavy metals. Environmental Science and Technology Briefs for Citizens. 2009; (15): 1-6.

[30] Smith AH, Lingas EO, Rahman M. Contamination of drinking-water by arsenic in Bangladesh: a public health emergency. Bulletin of World Health Organization. 2000; 78(9): 1093-1103.

[31] Manahan SE. Environmental Chemistry (8th Ed). Boca Raton, CRC Press LLC. 2004; 276-281.

[32] Vasey DE, Fredericks SE, Shen L, Thompson S. Natural Resources and Sustainability: Volume 4 of Berkshire Encyclopedia of Sustainability. Berkshire Publishing Group, ISBN: 1933782544, 9781933782546. $2011 ; 218$.

[33] Roohani N, Hurrell R, Kelishadi R, Schulin R. Zinc and its importance for human health: An integrative review. Journal of research in medical sciences: the official journal of Isfahan University of Medical Sciences. 2013; 18(2): 144-157.

[34] Hantke K. Bacterial zinc uptake and regulators. Current Opinion in Microbiology. 2005; 8: 196-202.

[35] Zayed A, Gowthaman S, Terry N. Phytoaccumulation of toxic trace elements by wetland plants: I. Duckweed (Lemna minor L.). Journal of Environmental Quality. 2014; 27: 715-721.

[36] Oliveira H. Chromium as an Environmental Pollutant: Insights on Induced Plant Toxicity. Journal of Botany. 2012; 375843: 8.

[37] Lewicki S, Zdanowski R, Krzyżowska M, Lewicka A, Dębski B, Niemcewicz M, Goniewicz M. The role of Chromium III in the organism and its possible use in diabetes and obesity treatment. Annal of Agricultural and Environmental Medicine. 2014; 21(2): 331-335.

[38] Sadeesh KR, Saranraj P, Annadurai D. Bio-adsorption of the toxic heavy metal chromium by using Pseudomonas putida. International Journal of Research in Pure and Applied Microbiology. 2012; 3: 2277-3843.

[39] Matthews NH, Fitch K, Li WQ, Morris JS, Christiani DC, Qureshi AA, Cho E. Exposure to Trace Elements and Risk of Skin Cancer: A Systematic Review of Epidemiologic Studies. Cancer epidemiology, biomarkers \& prevention: a publication of the American Association for Cancer Research, cosponsored by the American Society of Preventive Oncology. 2019; 28(1): 3-21.

[40] Schroeder HA, Nason AP, Tipton IH. Chromium deficiency as a factor in atherosclerosis. Journal of Chronic Disease. 1970; 23(2): 123-142. 
[41] O'Brien T, Xu J, Patierno SR. Effects of glutathione on chromium-induced DNA crosslinking and DNA polymerase arrest. Molecular Mechanisms of Metal Toxicity and Carcinogenesis. US: Springer. 2001; 173-182.

[42] Matsumoto ST, Mantovani MS, Malaguttii MIA, Dias AL, Fonseca IC, Marin-Morales MA. Genotoxicity and mutagenicity of water contaminated with tannery effluents, as evaluated by the micronucleus test and comet assay using the fish Oreochromis niloticus and chromosome aberrations in onion root-tips. Journal of Genetic Molecular Biology. 2006; 29(1): 148-158.

[43] Chatterjee S, Mukherjee A, Roy AS. Bioremediation of lead by lead-resistant microorganisms, isolated from industrial sample. Advance of Bioscience and Biotechnology. 2012; 3: 290-295.

[44] Sapale G, Patil B, Chaitanya R, Sawant N. Isolation and Characterization of Lead Metal Resistant Bacteria for Its Prospects in Bioremediation of Contaminated Soil. International Journal of Scientific Research. 2015; 4: 294-296.

[45] Ladele JI, Fajolu IB, Ezeaka VC. Determination of lead levels in maternal and umbilical cord blood at birth at the Lagos University Teaching Hospital, Lagos. PloS one. 2019; 14(2): e0211535.

[46] Wani AL, Ara A, Usmani JA. Lead toxicity: a review. Interdisciplinary toxicology. 2015; 8(2): 55-64.

[47] Alina M, Azrina A, Mohd Yunus AS, Mohd Zakiuddin S, Mohd Izuan Effendi H, Muhammad Rizal R. Heavy metals (mercury, arsenic, cadmium, plumbum) in selected marine fish and shellfish along the Straits of Malacca. International Food Research Journal. 2012; 19(1): 135-140.

[48] Castagnetto JM, Hennessy SW, Roberts VA, Getzoff ED, Tainer JA, Pique ME. MDB: the metalloprotein database and browser at the Scripps Research Institute. Nucleic Acids Research. 2002; 30(1): 379-382.

[49] Wadhwa N, Mathew BB, Jatawa S, Tiwari A. Lipid peroxidation: mechanism, models and significance. International Journal of Current Science. 2012; 3: 29-38.

[50] Patrick L. Mercury toxicity and antioxidants: Part 1: role of glutathione and alpha-lipoic acid in the treatment of mercury toxicity. Alternative Medical Review. 2002; (6): 456-471. 